\title{
Treatment of One Case with Cryoglobulinaemia Secondary to Connective Tissue Disease with Small Doses of Rituximab \\ X Wang ${ }^{1}$, Y Ning ${ }^{2}$, L Wang ${ }^{1}$, J Zhang ${ }^{1}$, Y Wang ${ }^{1}$, H Shen ${ }^{1}$
}

\begin{abstract}
Objective: This study aims to observe the clinical efficacy of low-dose rituximab in patients with cryoglobulinaemia secondary to connective tissue diseases.

Methods: Rituximab (100 mg) was infused in patients once a week for four weeks, combined with prednisone (20 mg) once a day, and reduced regularly. Treatment effect was observed regularly.

Results: Joint pain, fever, rash and fatigue symptoms in patients eased. The serology (globulin, erythrocyte sedimentation rate, $C$-reactive protein, lactate dehydrogenase and others) parameters returned to normal.

Conclusion: Low-dose rituximab therapy for cryoglobulinaemia secondary to connective tissue diseases was safe and effective, and can be used as a treatment option in this condition.
\end{abstract}

Keywords: Connective tissue disease, cryoglobulinaemia, rituximab

\section{Tratamiento de un caso con crioglobuleinemia secundaria a la enfermedad del tejido conectivo mediante pequeñas dosis de Rituximab}

\author{
X Wang ${ }^{1}$, Y Ning ${ }^{2}$, L Wang ${ }^{1}$, J Zhang ${ }^{1}$, Y Wang ${ }^{1}$, H Shen ${ }^{1}$
}

\begin{abstract}
RESUMEN
Objetivos: Este estudio tiene como objetivo observar la eficacia clínica de bajas dosis de rituximab en pacientes con crioglobuleinemia secundaria a enfermedades del tejido conectivo.

Métodos: Rituximab (100 mg) fue infundido en los pacientes una vez por semana durante cuatro semanas, combinado con prednisona (20 mg) una vez al día, y reducido regularmente. El efecto del tratamiento se observó regularmente.

Resultados: El dolor de las articulaciones, la fiebre, la erupción cutánea y los síntomas de fatiga en los pacientes, se aliviaron. Los parámetros de la serología (globulina, tasa de sedimentación eritrocítica, proteína C reactiva, deshidrogenasa del lactato y otros) volvieron a la normalidad.

Conclusión: La terapia de baja dosis de rituximab para la crioglobuleinemia secundaria a las enfermedades del tejido conectivo, resultó ser segura y eficaz, y puede ser utilizada como una opción en el tratamiento en esta condición.
\end{abstract}

Palabras claves: enfermedad del tejido conectivo, crioglobuleinemia, rituximab

West Indian Med J 2016; 65 (2): 398

\section{CASE REPORT}

This study was conducted in accordance with the Declaration of Helsinki and with approval from the Ethics Committee of Lanzhou University. Written informed consent was obtained from the participant. A male patient, aged 38 years, was admitted to our hospital in December 2011 mainly because his hands were turning purple in cold weather over 24 years, rash on face and limbs for seven years, which worsened over three months, with intermittent fever for two weeks. The patient

From: ${ }^{1}$ Department of Rheumatology and ${ }^{2}$ Department of Nephropathy, the Second Hospital of Lanzhou University, Lanzhou 730030, China. narrated that his hands turned purple or red in cold weather. There was no paraesthesia, and the hands returned to normal after being warmed. There was no fever, no mouth ulcers, no hair loss, no light allergy, no joint swelling and pain in 24 years. The above symptoms worsened every winter, and he received no treatment. Seven years before the admission, a dark red rash appeared on his face in the winter; the cheek and forehead, nose tip and ears were especially affected, while the dark red on the dorsum of the hands and both ankles were not 
more than the skin rash. There was no scaling, exudation, nor skin necrosis. The local rash was relieved after the skin was warmed. Chinese medicine and topical medications were used (the specific drug was unknown), but the symptoms did not remit fully. Two years before admission, the facial rash matology unit of a local hospital where he was diagnosed with connective tissue disease or discoid lupus erythematosus. Topical medications were given, but the efficacy was poor. The patient was then treated in the Rheumatism Immunity Division of a 3-A-grade hospital. The ANA positive particle type was examined to be 1:100; anti-U-RNP antibody was positive. The skin biopsy showed that the dermal layer had IgM deposition, the regular blood examination showed the white blood cell (WBC) was $2.1 \times 10^{9}$. He was diagnosed to have systemic lupus erythematosus. The symptoms were relieved, and later symptoms disappeared after taking $20 \mathrm{mg} q d$ prednisone, 0.2 g bid hydroxychloroquine and 0.6 tid pavlin for four months. The rash on his face and limbs occurred every winter, but no treatment was carried out. Three months before admission, the face and limb rash worsened. Intermittent fever appeared two weeks prior, and his body temperature reached up to $39^{\circ} \mathrm{C}$, while both wrist joints, knees, shoulder joints, and both bilateral ankle pains appeared, with no joint swelling.

At outpatient follow-up, regular urine showed urine protein, no blood. On regular blood examination, WBC was 1.7 $\times 10^{9} / \mathrm{L}$. The patient was admitted for further treatment with a diagnosis of connective tissue disease. Admission examination revealed stable vital signs, the cheeks, forehead and ears had a dark red rash, which was slightly more than the skin, no blanching when pressed, no itching, no desquamation or exudation; both hands dorsally and both ankles laterally had dark red rash but not more than the skin, blanched when pressed and which disappeared after warming. There were significant mandibular lymph nodes of the jaws, with size of $2 \times 1 \mathrm{~cm}$, moveable, and which were not tender and not fixed to underlying tissue. The respiratory system, abdomen, and the rest of the physical examination were normal.

Admission laboratory tests were: WBC $1.63 \times 10^{9} / \mathrm{L}$ $\downarrow$, haemoglobin $(\mathrm{Hb}) 10^{2} \mathrm{~g} / \mathrm{L} \downarrow$, red blood cells (RBC) 2.82 $\times 10^{12} / \mathrm{L} \downarrow$, platelet (PLT) $120 \times 10^{9} / \mathrm{L}$; urine: urine protein (-) red blood cell (-); shit (-); erythrocyte sedimentation rate (ESR) $53 \mathrm{~mm} / \mathrm{h} \uparrow$, C-reactive protein (CRP) $36.4 \mathrm{mg} / \mathrm{L} \uparrow$; biochemical examination: $\operatorname{IgG} 26.1 \mathrm{~g} / \mathrm{L} \uparrow(8-16), \operatorname{IgA} 3.46 \mathrm{~g} / \mathrm{L} \uparrow$ (0.7-3.3), IgM $0.63 \mathrm{~g} / \mathrm{L}$; normal complement $\mathrm{C} 3$, C4; phosphorus $1.58 \mathrm{~g} / \mathrm{L} \uparrow(0.8-1.45)$, magnesium $1.25 \uparrow(0.7-1.2)$, lactate dehydrogenase (LDH) $445 \quad \mathrm{U} / \mathrm{L} \quad \uparrow \quad(0-240)$, hydroxybutyrate dehydrogenase (HBDH) $352 \mathrm{U} / \mathrm{L} \uparrow$ (0-250); the remaining was normal. Twenty-four hour urine protein quantification: $0.36 \mathrm{~g} / 24$ hours; urine Bence Jones protein was negative; se-rum electrophoresis $\kappa, \lambda$ were negative; serum globulin: $42.4 \mathrm{~g} / \mathrm{L} \uparrow(0-20)$; autoantibodies: positive ANA, cytoplasmic granules type was 1:320, negative anti-SM antibody, negative anti-ds-DNA antibody, SSA, negative SSB, negative anti-U-RNP antibody, negative ANCA, negative anti-CCP, negative RF and negative ACA.
The examinations for infectious diseases were all negative; negative anti-tuberculosis antibody and purified protein derivative (PPD); positive cold globulin $(5.1 \mathrm{~g} / \mathrm{L})$, ophthalmic examination showed no xeroma, bone marrow biopsy showed megaloblastic anaemia. The chest radiograph was normal and likewise the electrocardiogram (ECG), abdominal B and echocardiography.

The patient was diagnosed with cryoglobulinaemia secondary to undifferentiated connective tissue disease after admission. He was prescribed $20 \mathrm{mg} q d$ prednisone (Wuhan Xinxinjiali Bio-Tech Co, LD, Wuhan, China) and $100 \mathrm{mg} \mathrm{qw}$ rituximab (Roche/Genentech, USA) for four weeks, while $600 \mathrm{mg}$ bid calcium carbonate (Jilin Wangtong Pharmacy Group Co, Jilin, China), $0.25 \mu \mathrm{g} q d$ calcitriol (Roche Pharma (Schweiz) Ltd, Basel, Switzerland), vitamin $\mathrm{B}_{12}$ (Shanxi Yunpeng Pharmaceutical Co, Ltd, Shanxi, China), folic acid tablets (JiangsuYabang Aipuseng Pharmaceutical Co, Ltd, Jiangsu, China) and other symptomatic and supportive treatments were given. One week after treatment, the patient's joint pain and febrile symptoms were relieved, the dark red rash on his hands and ankles faded, the red rash on his face and cheeks faded and decreased in extent; the fatigue symptoms were subjectively relieved. After being treated with the above therapy for two weeks, $50 \mathrm{mg}$ bid cyclosporine (Hangzhou Sino-US Pharmaceutical Co, Ltd, Hangzhou, China) was added to the treatment; four weeks later, no special discomfort was reported, there was no joint pain or fever and rash on hands, ankles, cheeks and forehead subsided and his skin returned to normal. On review of blood result: WBC $4.6 \times 10^{9} / \mathrm{L}, \mathrm{Hb}$ $122 \mathrm{~g} / \mathrm{L}, \mathrm{RBC} 4.32 \times 10^{12} / \mathrm{L}$, PLT $220 \times 10^{9} / \mathrm{L} ;$ ESR $10 \mathrm{~mm} / \mathrm{h}$ and CRP $5.0 \mathrm{mg} / \mathrm{L}$. Immune biochemistry showed: $\operatorname{IgG} 11.2$ g/L, IgA 2.40 g/L, IgM $0.42 \mathrm{~g} / \mathrm{L}$; complement C3, C4 were normal; LDH $220 \mathrm{U} / \mathrm{L}, \mathrm{HBDH} 204 \mathrm{U} / \mathrm{L}$ and review of cryoglobulins was negative. The result of 24-hour urine protein was $0.25 \mathrm{~g} / 24$ hours. The patient's symptoms improved and he was discharged on $15 \mathrm{mg} q d$ prednisone, $50 \mathrm{mg}$ bid cyclosporine, $0.2 \mathrm{~g}$ bid hydroxychloroquine (Shanghai Zhongxi Pharmaceutical (Group) Co, Ltd, Shanghai, China), $200 \mathrm{mg}$ bid calcium carbonate, $0.25 \mu \mathrm{g} q d$ calcitriol, vitamin $\mathrm{B}_{12}$ and folic acid treatment. He was followed-up for six months; no fever, arthritis or skin rashes recurred, and no serious infections or other adverse reactions occurred.

\section{DISCUSSION}

Cryoglobulin is a protein that could have reversible precipitation at low temperatures (less than $4{ }^{\circ} \mathrm{C}$ ) and which dissolves at around $37^{\circ} \mathrm{C}$. The increase of blood cryoglobulin levels ( $>250 \mathrm{mg} / \mathrm{L}$; cryoglobulinaemia) can cause a series of symptoms, such as rash, joint pain and weakness, and also involves the kidneys, liver and peripheral nervous system. Cryoglobulinaemia is divided into primary and secondary, and the latter represents the majority (accounting for $60 \%-75 \%$ ), which can be secondary to connective tissue diseases such as systemic lupus erythematosus, vasculitis, systemic sclerosis and, Sjogren's syndrome, can lead to malignancies such as multiple myeloma, lymphoma, liver cancer and chronic 
lymphocytic leukaemia, as well as secondary to chronic infectious diseases such as hepatitis, syphilis and leishmaniasis (1). Cryoglobulins are actually immunoglobulins, and can be divided into three types according to the different types of immunoglobulin in precipitation (2): Type I is a monoclonal type, Types II and III are mixed types. Type I is common in multiple myeloma and Waldenstrom macroglobulinaemia. Types II and III cryoglobulinaemia have at least two types of immunoglobulin, and are found in a variety of diseases, such as autoimmune diseases, lymphoproliferative disorders and liver disease [hepatitis B or hepatitis C] (3). The index case has a history of 24 years with repeated rashes and arthritis in cold weather, high globulin, white blood cells and haematoblast were decreased and urinary protein was mildly elevated; ANA was positive, cytoplasmic granules type was 1: 320 . On admission at a previous hospital, he had positive U-RNP antibody, with IgM deposition in the dermal layer on skin biopsy. Although he was diagnosed with systemic lupus erythematosus in another hospital, the authors believe that the patient's long history (24 years), no improvement in the disease with standard treatment for lupus and with no major organ involvement or progression, the diagnosis of systemic lupus erythematosus was questionable. The patient was finally diagnosed with undifferentiated connective tissue disease, which induced secondary cryoglobulinaemia. He had increased IgG and IgA, suggesting Type III cryoglobulinaemia.

Traditional treatment for cryoglobulinaemia is mainly hormones, immunosuppressive agents (such as cyclophosphamide), chlorambucil, interferon and plasmapheresis and other methods (4). Rituximab is a chimeric monoclonal antibody that could bind with B cell surface antigen CD20. The infusion of rituximab can effectively remove B cells and plasma cells from the body to interrupt the synthesis of monoclonal IgM and cold globulin $(5,6)$. Rituximab can be used for the treatment of connective tissue diseases $(7,8)$ and cryoglobulinaemia. Zaja et al, in 2003 (9), reported the efficacy and safety of treatment for Type II cryoglobulinaemia by rituximab; subsequently, other authors have also reported on rituximab as treatment for cryoglobulinaemia $(10,11)$. In 2011, Ferri et al (11) reported the results of a retrospective study on treatment of mixed cryoglobulinaemia with rituximab. Thirty-nine published reports $(\mathrm{n}=279$ patients $)$ on rituximab treating mixed cryoglobulinaemia were included in the review. The retrospective study included 87 cases with cryoglobulinaemic vasculitis; hepatitis C occurred in $92 \%$. Regardless of the presence or absence of hepatitis $\mathrm{C}$ virus infection, monotherapy for six months resulted in significant clinical and serological remission, and confirmed the safety of the treatment during follow-up in six months (11). The patients in this report had associated connective tissue disease and because they had prolonged leukopenia and reduced symptoms, cyclosporine and corticosteroids were additionally used. After rituximab, cyclosporine, prednisone and hydroxychloroquine treatment, the symptoms disappeared. There was no recurrence in longterm follow-up and no serious adverse reactions (11).

Rituximab for treatment of cryoglobulinaemia secondary to autoimmune diseases was safe and effective. For relapsed or refractory patients, it can be used as a treatment option, but its exact efficacy and safety issues need to be confirmed by further research and clinical studies.

\section{CONFLICT OF INTEREST}

All authors have no conflict of interest regarding this paper.

\section{REFERENCES}

1. Terrier B, Cacoub P. Cryoglobulinaemia vasculitis: an update. Curr Opin Rheumatol 2013; 25: 10-8.

2. Quartuccio L, Isola M, Corazza L, Ramos-Casals M, Retamozo S, Ragab GM et al. Validation of the classification criteria for cryoglobulinaemic vasculitis. Rheumatology (Oxford) 2014; 53: 2209-13.

3. Michaud M, Pourrat J. Cryofibrinogenemia. J Clin Rheumatol 2013; 19: $142-8$

4. Ferri C, Mascia MT. Cryoglobulinemic vasculitis. Curr Opin Rheumatol 2006; 18: 54-63.

5. Arzoo K, Sadeghi S, Liebman HA. Treatment of refractory antibody mediated autoimmune disorders with an anti-CD20 monoclonal antibody (rituximab). Ann Rheum Dis 2002; 61: 922-4.

6. Smith MR. Rituximab (monoclonal anti-CD20 antibody): mechanisms of action and resistance. Oncogene 2003; 22: 7359-68.

7. Keir GJ, Maher TM, Hansell DM, Denton CP, Ong VH, Singh S et al. Severe interstitial lung disease in connective tissue disease: rituximab as rescue therapy. Eur Respir J 2012; 40: 641-8.

8. Duxbury B, Combescure C, Chizzolini C. Rituximab in systemic lupus erythematosus: an updated systematic review and meta-analysis. Lupus 2013; 22: 1489-503.

9. Zaja F, De Vita S, Mazzaro C, Sacco S, Damiani D, De Marchi G et al. Efficacy and safety of rituximab in type II mixed cryoglobulinaemia. Blood 2003; 101: 3827-34.

10. De Vita S, Quartuccio L, Fabris M. Rituximab in mixed cryoglobulinaemia: increased experience and perspectives. Dig Liver Dis 2007; 39 (Suppl 1): S122-8.

11. Ferri C, Cacoub P, Mazzaro C, Roccatello D, Scaini P, Sebastiani M et al. Treatment with rituximab in patients with mixed cryoglobulinaemia syndrome: results of multicenter cohort study and review of the literature. Autoimmun Rev 2011; 11: 48-55. 